\title{
ACCOUNTING ADJUSTMENTS FOR THE \\ CALCULATION OF EVA: STUDY OF THE PROCEDURES USED AT BRAZILIAN COMPANIES
}

\author{
Leonardo Fernando Cruz Basso*
}

Faculdade de Ciências Econômicas, Contábeis e Administrativas

Universidade Presbiteriana Mackenzie

Silvia de Franco de Oliveira

Administração de Finanças e Banking

Centro Universitário Nove de Julho

Eduardo Kazuo Kayo

Faculdade de Ciências Econômicas, Contábeis e Administrativas

Universidade Presbiteriana Mackenzie

(Received 8 July 2005, accepted 26 September 2005)

\begin{abstract}
The shareholder value creation is becoming an answer to the pressure of the investors and councils. Many approaches are available. Among them, the Economic Value Added (EVA), developed by Stern Stewart \& Co. To correct the improprieties perceived in financial statements, some users of EVA adjust the income numbers based on the Generally Accepted Accounting Principles (GAAP), expecting that such adjustments may produce more trustworthy values and generate an environment favorable to a management behavior closer to the optimum. Besides that, this work investigates the correlation between the brazilian controller understanding and the use of the company adopted accounting methods.
\end{abstract}

\section{Resumen}

La generación de valor para el accionista se está volviendo una preocupación cada vez más presente en respuesta a la presión de los inversionistas y directorios de sociedades. Varios abordajes están disponibles, entre estos, una línea de pensamiento ligada a la Ganancia Resídual, el Valor Económico Agregado (EVA), metodología desarrollada por Stern Stewart \& Co. Para corregir las impropiedades notadas en la práctica de los estados financieros, algunos usuarios de la técnica del EVA ajustan los datos contables de acuerdo con los Principios Contables Generalmente Aceptados, en la expectativa de que dichos ajustes produzcan valores más confiables y puedan generar ambiente propicio a los comportamientos administrativos más próximos al óptimo esperado. La lógica y la mecánica por detrás de esos ajustes son tratadas a lo largo del trabajo, investigando la posible correlación entre la percepción de entendimiento del controller y la utilización de los métodos adoptados por la organización.

JEL classification: $M 41$

Keywords: Economic Value Added (EVA), Shareholder Value Creation, Generally Accepted Accounting Principles (GAAP), Financial Drivers

* Universidade Presbiteriana Mackenzie. Rua da Consolação, 930, 7 andar. Sala 76. Consolação. São Paulo-SP. CEP 01302-907. Telephone: +55(11)3236-8597. E-mail: leonardobasso@mackenzie.com.br; eduardo.kayo@mackenzie.com.br; 40187594@mackenzie.com.br 


\section{Introduction}

According to Frezatti (2003, p. 13), Copeland (1994) and Rappaport (1981), value-based management reconciles the interests of the chief agents, since it orients the planning process, through the setting of goals, to balance the short, medium and long-term objectives, i.e., the value of the organization and the daily managerial results, guaranteeing the optimization of shareholder value.

Doucouliagos $(1994$, p. 877) considers that decision makers take into account the cognitive skill of exercising rational choices that are limited as regards gathering, processing and analyzing information, in other words, the decision maker is obliged to do so with limitations imposed by his or her own cognitive limitations, and by various numerical issues.

The potentiality of information in the hands o the decision maker must be understood to permit its adequate use, taking into consideration the limitations of information systems, such as the available methodology, the handling potential, sources of information, temporal conditions and traits of the business (Frezatti, 1996, p. 8).

In this approach, the discussion of the work is focused on the type of information that can make decision-making feasible. Said information is identified, gathered, prepared and placed at the disposal of the decision maker, changing into a model that allows the agent to make the decision.

In this study accounting proposes to act as an adequately structured data base, founded on a defined methodology, which does not eliminate risks of error, but permits a better explanation of the causes, providing feedback to the company's value projection and allowing the manager to decide about the demands related to the various decision-making processes associated with the organization, from various approaches or outlooks.

Frezatti (2003, p. 19) observes that there are two ways of describing the connection between accounting and decision-making and the appraisal of performance at the organization. The first through the observation, analysis and tracking of economic events already verified, implying the distribution of dividends or future investment potential. The second, based on the fundamentalist theory, pursuing the projection of results that depend on the scenarios perceived by the decision maker and by the capacity to translate these elements into numerical information.

The consequence of this approach is that the organization starts to have a proactive outlook as it seeks to control its own future by reviewing its business strategies and projected results in order to protect the value of the company.

In this context, this paper contains a discussion of the interaction and conflict between the prescriptive approach, which presents how information should be gathered and prepared for the decision process, and the descriptive approach, whose real interest constitutes identifying how the information is actually gathered and prepared (Hendriksen and Breda, 1992, p. 198).

Furthermore, the authors of this paper also consider it important to understand, by means of an onsite survey, the status quo of companies in the country in terms of the mix of managerial information, seeking in empirical evidence traces that enable us to understand (or emphasize) the issue, its limitations and opportunities. From this perspective, the question that the authors intend to 
answer is: is there a relation between the definition of the method adopted by Managerial Accounting in the organization and the controller's perception in relation to the method of approximating the book value to the economic event and its respective frequency of use? Along this line of reasoning, the general objective of this study is to verify whether there is a relation between the definition of the method adopted by Managerial Accounting in the organization and the controller's perception in relation to the method of approximating the book value to the economic event.

Using the knowledge acquired by the review of literature, the following objectives are required for this paper:

- Identify the use of accounting instruments for management at the organization via Managerial Accounting;

- Investigate the possible correlation between the controller's perception of understanding as concerns the approximation of the book value and the economic value and the use of methods adopted by the organization from May to October 2003;

- Observe whether the adjustments defined in managerial accounting approximate the book value and the economic value according to the controllers' perception.

\section{Bibliographical Review}

\subsection{Value Calculation and Management Methodology}

According to Steiner, apud Frezatti (2003, p. 39), the long-term indicator that can be used in the strategic planning process should be: linked to the organization's purpose, i.e. mission and values; subject to measurement during a certain period of time; feasible in terms of attainment; acceptable by the people from the organization; flexible; motivating; understandable (simple); capable of producing a commitment by those that will be developing the actions; participative, in its definition, by professionals; and consistent at the various hierarchical levels and in the organization.

Various alternatives are available and are mentioned in literature as potential long-term financial indicators suitable for monitoring the development of operations from the perspective of the unification of the understanding of economic events. According to Frezatti (2003, p. 32) the indicators include those that connote: Internal variable (return on investment - ROI, discounted cash flow and residual income) and External variable (value of the company and its MVA). The residual income (RI) approach related to the internal variable is summarized and transcribed below.

\subsubsection{Residual Income}

According to Johnson and Kaplan (1996, p. 143): "the development of the RI procedures is usually attributed to General Electric Company, even though the idea of mandating an explicit capital charge on investments, in the computation of net income, already figures in various foregoing literary works from this century [20th century]. The concept of residual income only appears in managerial accounting literature in the $60 \mathrm{~s} "$. 
Anthony, apud Frezatti (1998, p. 62) defines residual income "(..) as a value that is obtained by subtracting the cost of invested capital from income. This capital cost is obtained via the multiplication of the value of assets employed by a given rate".

In simple terms, residual income is what remains for the organization after it remunerates, pays and returns financial resources consumed in its process, thus involving the shareholders, financial institutions, suppliers, employees and service providers.

Various alternative metrics that summarize economic performance have appeared since the topic is widely studied in international academic circles. In relation to the residual income method we have: Economic Value Added (EVA) by Stern Stewart; Total Business Return (TBR) by Boston Consulting Group; LEK by Alcar Consulting Group; Shareholder Value Added (SVA) by Rapapport; HOLT by Holt Value Associates and Cash-flow Return on Investment (CFROI).

Frezatti (1998, p. 59) describes some strong points of the calculation of residual income:

- Presents a simplified conceptual language;

- Constitutes an additional product of accounting and not its rival;

- Affords the analysis of internal performance (remuneration policy), analysis of investment (for acquisition/merger/takeover purposes) and market analysis of the organization;

- Determines the income that remunerates all the stakeholders involved, taking the risk into consideration;

- Permits the preparation of benchmarking, when used in external analysis, through the comparison of the organization's performance in terms of operating return, capital cost and investment management;

- Permits the reduction of accounting distortions through the suggestion of adjustments.

The author (2001, p. 49) also indicates some limitations in the implementation of this value:

- Subjectivity related to the criteria defined for each organization: the need for assumptions about the share of own and third party funds in the calculation of the opportunity cost; and difficulty in understanding the meaning of economic result;

- Complexity of the instruments for its implementation in the organization, calling for maturity from the management group and a refined information system.

Carvalho (1999, p. 43-44) declares that the performance of valorization based on a simple criterion (EVA) tends to encourage managers to manipulate the performance indicators, distorting the benefits and the limitations of use of the indicator. He also adds, as a negative aspect, that the indicator discerns the added value arising from the success of strategic decisions and investments from a past accounting period, not considering the evaluation of the organization, to the effect of knowing whether it is acting to guarantee its sustainable competitive advantage. 
The author (1999, p. 49-50) observes that the use of EVA at companies has produced some effects, with an emphasis on:

- Enhanced awareness of the value of capital on the part of management;

- More enterprising management, seeking alternative ways of increasing the value of the organization, although in a more adequately planned fashion;

- Performance appraisal henceforth uses as parameter the profitability offered by the market in the investment of the capital involved and no longer against results of the sector;

- Business unit management indicator and operational and functional indicators, permitting the tracking of the potential gain of each implemented improvement.

\subsection{Necessary Adjustments in the Accounting Data for the Obtain- ment of the Economic Result}

Frezatti (2001, p. 50) analyzes the accounting principles presented by Hendriksen (entity, continuity, periodicity, conservativeness, monetary common denominator, realization, comparison of income and expenses related thereto and competence of the year) with the objective of verifying its validity both in the economic result approach and in the result by accounting principles, so that, in cases where differences occur, some type of adjustment is identified to maintain equality. To this effect, three types of adjustments are identified: adjustment to obtain the economic operational result and the base of investments that produces said result; adjustment to expurgate values that do not necessary imply economic/cash impact; and adjustment to expurgate non-recurrent gains and losses.

Young (1999, p. 12) suggests that the organization should consider one of the four following situations before it opts for an adjustment:

- Is there is distortion or bias caused by the accounting practice that result in a behavior below the expected level?

- Will the adoption of the adjustment provoke an improvement in the managerial behavior thereby stimulating actions that aid in the creation of value?

- Are the benefits resulting from the improvement of managerial performance greater than the costs resulting from the alterations in accounting practices?

- Are the adjustments more efficient in attaining the desired objectives than alternative or control mechanisms?

In other words, applicability might or might not occur in the organization, not only due to the organization's concern about assuming a standpoint with respect to the adjustment needed to bring about the desired economic result, but also due to the actual judgment and common sense of the manager when these adjustments are evaluated from the perspective of Managerial.

\subsubsection{Type 1 Adjustments}

The result prepared in accordance with accounting principles underestimates information related to the remuneration of shareholders arising from the use 
of own capital in the organization, producing distortions in comparison to the economic result, which determines net information on all the factors to be remunerated (conservative outlook). Accordingly, some adjustments should be made in order to permit the adequate determination of income, the identification of investments in financial resources that have produced said income and the comparison with the cost of capital.

According to Frezatti (2001, p. 53) type 1 adjustments are adjustments of the moment, since the moment can make the result different at a given instant, and although compensated at another moment, the present value will not be compensated. The following items were selected for this group: research and development, amortization of goodwill, leasing, deferred income tax and depreciation.

\subsubsection{Research and Development (R\&D)}

Milani (1982, p. 102) observes that most companies prove resistant to the capitalization of $\mathrm{R} \& \mathrm{D}$ costs, on account of one of the following arguments:

- The amortization of current expenses constitutes a conservative rule;

- Results with R\&D are always uncertain;

- The literature referring to the topic does not contain sufficient information to consistently distinguish the two accounting classification alternatives.

Young and O'Byrne (2000, p. 212) argue that expenses with R\&D are investments; in some cases they pay for themselves, and in others not, but this does not mean that they are not investments. Hence the authors advocate the capitalization of these expenditures. Another aspect in favor of capitalization is related to the dysfunctional behavior of the officers and directors.

In the opinion of Young $(1999$, p. 5) the practice prevents officers and directors from having unfavorable behaviors in relation to R\&D investors, as they are evaluated by the result expected from the business unit and this is unfavorably influenced on the short term as a result of the appropriation of expenses, and favorably influenced on the long term when the investment benefits occur (the same manager that decided on the investment is not always the one that will manage the business two or more years later on).

\subsubsection{Goodwill and Respective Amortization}

There are various classifications of goodwill, which adopt different names for the various benefits that the company can obtain. However, the focus of this item is acquired goodwill, i.e., the goodwill that appears at the investor upon the purchase of a given capital holding or when an additional quota of interest is acquired.

Sundararajan (2002, p. 5) clarifies that amortization qualifies companies for the combination of the cost of the intangible asset and the benefits arising from its acquisition, preventing abuse in the projection of unreal future gains. The author also observes that, after the decision relating to amortization, the focus is turned towards the maximum period of amortization, which permits the least impact on the income statement.

However, the author (2002, p. 5) observes that the rationality of nonamortization is based on the notion that goodwill does not decrease in value. 
The strong skills of management, the good name and reputation, and the excellence of the work team do not usually decrease in value. Rather, the opposite occurs. In these terms, in his opinion, goodwill should be considered an investment and should be kept intact in the balance sheet.

Frezatti (2001, p. 54) also agrees that appropriation criteria are overly arbitrary, but considers that any asset has a useful life to be considered in its treatment and that the non-appropriation of value overestimates the value of assets in the organization. In his opinion, the treatment to be established should be defined through a case-by-case analysis, both as refers to adjustment and to amortization.

Young and O'Byrne (2000, p. 239) observe that the core of the issue is how goodwill is classified. Along these lines, the authors present three classification options:

- Consumable fixed assets that are recovered through positive amortization rates;

- Non-consumable fixed assets, which do not suffer value alterations and do not require amortization rates;

- Assets that suffer alterations in their value, and that are recognized through negative amortization rates.

If the goodwill is considered a non-consumable fixed asset, realized amortization should be added to the income in order to restore the original value of the invested capital.

Nevertheless, Young and O'Byrne (2000, p. 240) observe that the analysis continues to present a performance measurement problem, since the write-off of direct goodwill against income does not alter the business evaluation analysis, but incorrectly implies the perception of the first year as extremely poor in terms of performance. In any year chosen for the write-off, the income, which is apparently bad, will not be related to the operational performance of the business in any way. Once again, the figures seem to say that acquisition destroys value, even though investors are gaining a return corresponding to the cost of capital on the market value every year.

According to Young and O'Byrne (2000, p. 243), even though negative economic depreciation is a perfectly correct solution to the acquisition problem, it is more common for companies to use a pro-forma annual base to prevent the discouragement of value-generating acquisitions. Hence the acquired goodwill is included in a pro-forma base, in the capital invested in the previous year, eliminating the bias of incentive plans against acquisitions. To complete this, he suggests that companies up their goals for improvement, in that acquisition leads to stable growth in income.

Young and O'Byrne (2000, p. 244) observe that goodwill can be written off directly against shareholders' equity, on the acquisition date. In this case, goodwill will never appear in the balance sheet, thus there is nothing to amortize. The effect is an undervaluation of invested capital. However, since payment above the value of the assets represents an outlook of future gains, and since these possible gains tend to be recognized in shareholders' equity via retained earnings, Sundararajan (2002, p. 4) considers the offset entry appropriate. 


\subsubsection{Leasing}

According to Martins (2002, p. 3), lessees believe there is a gain when recording in the form of rent. However, if we observe that the total installments paid to the lessor correspond to the total cash price of the purchase of the asset plus increases due to the loan, and that this value corresponds to the total depreciation of the asset plus the financial charges, then the difference lies in its distribution over the course of time and not in the total expenses.

This more rapid appropriation undervalues operating income during the period in which the company is disbursing the installments. On the other hand, after the payment of the installments, there is an overvaluation of operating income and consequently of its profitability, until the end of the useful life of the asset, since the only expense to be entered is the residue of depreciation which, by the way, is symbolic, seeing that the value of the asset has already been paid and entered in full.

Martins (2002, p. 3) draws our attention to the fact that the lessee does not pay less income tax for the prepayment of expenses, since the lessor includes the cost of this tax that it pays when allocating the revenue of the installments (financing of this anticipated income tax at the lessor). It is for this reason, concludes the author, that the financing rate of leasing is higher than the normal financing rate.

The author $(2002$, p. 3$)$ adds that the merit of commercial leasing lies in the timeframe and in the scope of the financed part (100\%) and not in the tax benefits, which do not really exist. However, if the lessee does not record the lease in this way, he or she ends up paying for the financing of the tax, which burdens the lessor and, without the counter entry of postponing his or her own tax, incurs an effective fiscal and financial loss.

Young and O'Byrne (2000, p. 247) also analyze the influence of the accounting of leasing as a rent expense and conclude that the treatment undervalues the invested capital, as leasing is actually a debt. In performing the adjustment, the estimates of debts with third parties and own capital change, and consequently lead to the change of the weighted average cost of capital.

Likewise, operating income is also undervalued, since part of the leasing payments refers to interest, which should be classified as a financial expense, and not form the operating income (the tax benefit of interest, in turn, should also be subtracted from operating income).

The authors (2000, p. 252) observe that the effects of adjustments are only significant at companies with large volumes of leasing operations. However, if the authors take into consideration the allocation of the good as an asset, and its corresponding depreciation in accordance with the term of its useful life, they will realize that this change will have a significant influence on the interpretation of performance, and thus provoke changes of behavior in officers and directors. Hence, according to Frezatti (2001, p. 55), one should reverse the amount of leasing amortization from income, and from previous periods, and constitute it in the balance sheet to form part of the invested capital, to be allocated in the future. 


\subsubsection{Deferred taxes}

Leão et al. (2000, p. 5) informs that deferred income tax entered as income is determined in a residual fashion, i.e., with a difference between the initial and final balances of tax assets and liabilities deferred for the period. Using this logic, Young and O'Byrne (2000, p. 221) conclude that deferred tax liabilities always remain in the balance sheet, providing the company has situations that are benefited by postponement.

To this effect, as older temporal differences are reverted, new ones appear, so that deferred tax is more like own capital than third party capital. Hence since the liability will not be paid, the respective expense should not be recognized. However, according to the authors, the chief problem of this logic is the fact that it only occurs in the case of deferred taxes derived from depreciation at a company with maintenance of the investment level.

In addition to this problem, Young and O'Byrne (2000, p. 221), specify another two that make it impossible to adequately evaluate the value of business:

- The values of the free cash flow are underestimated, since tax liability is not recognized in terms of present value;

- The return on the invested capital is below the economic return.

For the first problem, the alternative suggested by the authors (2000, p. 222) is the recognition of the deferred tax expense in terms of present value. Leão $(2000$, p. 8) alleges that theoretically, said procedure could even eliminate the account of deferred taxes in situations where the period of time is long or infinite, to bring its present value close to zero.

However, overlooking the theoretical side, and passing over to the practical side, there are other difficulties involved such as the choice of discount rates and the accurate determination of future years in which the sums will be taxable or deductible.

In relation to the second problem, Young and O'Byrne (2000, p. 219) declare that, although the deferred tax expense does not sensitize the cash of the current period, it could reflect on a significant economic cost, since by ignoring the deferred tax liabilities, this could cause the company's performance to be overestimated. In this respect, Frezatti (2001, p. 55) proposes reversing the amount of allocation of deferred income tax from income and forming the balance sheet amount that will constitute the invested capital, in order to correct the operating income and the base of investments.

\subsubsection{Depreciation}

The most logical basis for the distribution of the cost of goods appears to be directly related to the accrued benefits, i.e., the net value of services rendered by the good in the different accounting periods. However, FIPECAFI (1994, p. 210) presents three advantages in the use of the decreasing method:

- Fiscal advantages: the higher quotas of depreciation at the beginning of the useful life mean lower taxes, although it is know that at the end, the taxes will be higher, as the depreciation quotas are lower;

- Reduction of the risk of loss: on account of the fact that the estimate of the useful life is almost always precarious, when a good is written off prior to 
the end of depreciation, the rest of the cost to be amortized is recorded as loss. Now, the lower the balance, the lower the loss to be allocated (e.g.: obsolescence of the asset);

- Greater uniformity in costs: when the goods are new, the nced for maintenance and repairs is insignificant. However, as they become older, there is a growth in maintenance and repair expenses, which is offset by the decreasing quotas of depreciation, resulting in more uniform overall costs.

Young and O'Byrne $(2000$, p. 229) are against the use of the decreasing method. The authors argue about the distortion caused by the depreciation of the straight-line method, when presenting increasing returns on the invested capital. If the company uses the method of decreasing quotas of depreciation, this distortion is accentuated.

They add that for the accounting rate of return to be equal to the economic rate of return, one must adopt the amortization fund method, which presents amortization quotas that are growing enough to maintain the return on invested capital constant and equal to the economic return throughout the period. Another form of equalizing the two rates occurs when the project sports decreasing operating margins in the period.

The authors (2000, p. 236) conclude that the amortization fund method (which presents increasing quotas of depreciation) is not adopted by companies, as it reduces the result in currency, which provokes difficulties in explaining the slump in performance throughout the period (in spite of the fact that the rates of return on invested capital have remained constant). This situation produces dissatisfaction among managers, if it is linked to bonus plans in accordance with the economic-financial performance.

They state that companies usually adopt the straight-line method of depreciation due to the favorable treatment for fiscal purposes. It is generally in the interest of taxpayers to exploit the highest deductions admitted by law to recover invested capital as soon as possible through savings in the income tax arising from accelerations due to the increase in the number of shifts, to tax incentives and others.

Hence, the economic result can be interpreted as much more or much less favorable in a given period than it really should be as a result of the creation of compatibility between the real benefit and allocation, capable of provoking incorrect reactions and decisions on the short term. According to Frezatti (2001, p. 65) although understanding this effect is a simple task, no concern is perceived on the part of the organization in making the benefit compatible with allocation regardless of the impact experienced on the short term.

\subsubsection{Type 2 Adjustments}

Type 2 adjustments are those that present the need to expurgate values that do not necessarily imply economic impact or cash. The effects of adjustments of inventory movement and on allowances for guarantee, doubtful accounts and contingency are evaluated in this group.

\subsubsection{Inventory Valuation (LIFO/FIFO)}

According to FIPECAFI (1994, pp. 144-145), the attribution possibilities of this unit value (always based on the cost or value of acquisition) are: PEPS, UEPS and mobile weighted average: 
- PEPS: reversal in sales at the cost of the first purchases, i.e., the first merchandise purchased is sold or consumed first. Souza (2000, p. 32) observes that, from the accounting perspective, at the end of the accounting period, the inventory assets and liabilities will be evaluated by the most recent market values;

- UEPS: write-off in sales at the cost of the last purchase, i.e., the last merchandise purchased is consumed first. Souza (2000, p. 32) clarifies that in this case the company evaluates its inventory by historical values, recording in income the products evaluated by the most recent values. In an economy with growing inflation, the tendency to allocate the most recent costs to products made normally provokes a reduction in accounting profit and consequently, in income tax. However, according to Martins (1992, p. 99), when this inventory is used, the entire income not formerly previously will be recorded at this moment;

- Mobile weighted average: meaning a criterion in which the average value of each unit of inventory is altered by the purchases of other units at a different price. According to Martins (1992, p. 99), the method avoid the control of costs per batches of purchases, like in the previous methods, but entails a higher calculation number at the same time as it avoids extremes, providing and average purchase value as the acquisition cost.

Martins (1992, p. 101) calls our attention to the fact that these differentiated situations are compensated period after period, i.e., when the entire stock of material has been used up, the sum of the costs of materials applied by the various years will be equal. However, this situation only occurs if the company makes the purchases and sells them without the intention of continuing to operate, or when it works with zero inventory.

Young and O'Byrne (2000, p. 227) observe that the adoption of the UEPS method provokes two problems in the value creation indicator:

- In an inflationary economy inventories are substantially underestimated; consequently this also applies to the net assets and invested capital;

- When the inventories are liquidated, a situation that occurs when the inventories decrease from one year to the next, the operating income and the value creation indicator are overestimated as a result of the comparison between costs at historical prices and revenue at current prices.

The authors inform that the organizations that adopt this method present a stock reserve in the notes to their financial statements, and that this reserve is calculated by the difference between the inventory value and the current cost value. This reserve is added to the invested capital, and its annual variations are added to the operating income. Young (1999, p. 11) emphasizes that in economies with low inflation, and relative stability in the prices of factors, the benefit of the inventory adjustment is minimum.

Frezatti (2001, p. 57) adds another situation in which adjustment is necessary. When the organization decides to change the inventory movement criterion (e.g.: from FIFO to weighted average cost), not causing any influence on the cash flow, but affecting income. In this situation, he proposes the reversal of the allocation value of the change of criterion from income, and the formation of the balance sheet amount that will form part of the invested capital. 


\subsubsection{Allowance for Guarantee, Doubtful Accounts and Contingen- cy}

FIPECAFI (1994, p. 118) observes that the provision formed by the fiscal limits represents a healthy policy, but could produce significant distortions through over or undervaluation, not acceptable by accounting principles as they distort the financial statements and income of the company, as well as the corresponding dividends.

Young and O'Byrne (2000, pp. 225-226) inform that some EVA proponents argue that the formation of reserves is subjective and can serve as a manipulative tool to obscure the performance results of managers, besides provoking the distancing of the economic result and cash flow. If this argument is correct, the provision should be added to the operating income, and, to complete the reversal of the effect on the balance sheet, add the provision, net of the tax effect, to the invested capital.

Frezatti (2001, p. 57) adds that a careful analysis should be carried out to discover to what extent the provision reflects conditions normally observed at the company, since simply disregarding it does not constitute a healthy practice. In his opinion, when provisions are over dimensioned in relation to the perceived risk, they should be reversed from income, having as a counter entry an account that affects the invested capital.

\subsubsection{Type 3 Adjustments}

The objective of type 3 adjustments is to expurgate non-recurrent gains and losses, i.e., once identified, they should be expurgated from income.

\subsubsection{Non-Recurrent Gains and Losses}

Once identified, the occurrence of a single event, whose repercussion on income only occurs at a specific moment in time, should be expurgated from income, but evaluated and planned separately from recurrent income. This is the opinion of Frezatti $(2001$, p. 58) in relation to non-recurrent events, since in this manner there is a perception of what gives rise to the company's income under normal, routine conditions.

Young and O'Byrne (2000, p. 206) present a different approach to the topic. Using the oil exploration business as an example, the authors inform that many accountants defend the approach of removing the investments from the asset if an oil well results in a dry hole, without any prospects of generating a future cash flow.

However, according to the authors, if the costs of unproductive wells are written off as expenses, the project will appear to be extremely profitable, much more than it really is, furnishing inconsistent figures in the period. If the costs of dry wells are capitalized and amortized over the period of duration of the oil reserve, one will obtain a better picture of the performance of the project. In other words, the capitalization of the cost of dry wells makes the accounting return from the project closer to the economic return.

According to Young (1999, p. 4), by procecding in this fashion two important advantages stand out. Firstly, by maintaining the capital invested in the balance sheet, it becomes a constant reminder of the manager's obligation 
to obtain sufficient gains to return all the capital funds used. Secondly, the manager is left without the capacity to manage the recognition of loss, and therefore, to modify the data that forms the basis for the performance analysis. According to Young and O'Byrne (2000, p. 209) the practical effect of writing off unproductive investments at the organization, maintaining the most promising investments in the balance sheet, is no different from oil companies that enter the costs of their dry wells in income.

\subsubsection{Some Aspects to be Emphasized}

This chapter has explored an important and controversial aspect: the adjustment of operating income and invested capital to correct some deviations and distortions in the accounting figures based on accounting principles. The logic and mechanics behind the adjustments were discussed, and authors such as Young (1999) and Frezatti (2001, p. 67) concluded that:

- The adjustments developed to migrate from Accounting to the economic result arise from the need to analyze income differently, based on the return obtained in relation to its capital cost, allowing the organization to have the information contribute toward the management of the organization's value (Young 1999 , p. 1);

- The tool sports a higher potential for use in managerial accounting, since each organization can have different characteristics, requiring different adjustments, in accordance with its traits, size and profile of events (Young, 1999, p. 12);

- Adjustments contribute towards the improvement of managers' performance in decision-making (Young 1999, p. 12), especially if the tool is used as a basis for the calculation of variable remuneration;

- In spite of the equality between income by the cash flow and the economic return, differences occur throughout the period of analysis that could lead to a decision that is not the most suitable, which can be more detrimental than decisions provoked by a difference between the income presented by the cash flow and economic return.

\section{Methodology}

Once the conceptual issues have been covered, the work is focused on the obtainment of information that permits the analysis of empirical data:

- Nature of the study: In relation to the approach, the analytical empirical was used as a principal;

- Variables of interest: The survey is concerned with identifying the stateof-the-art in terms of managerial accounting practices in Brazil and the usefulness of Managerial Accounting for value management, in accordance with the profile of the company (formation of capital and segment) and profile of the respondent (gender);

- Population of the survey: The members of the survey group are Brazilian companies and the scope is national;

- Formation of the sample group: The survey was developed with a basis on a non-probabilistic approach, since: 
$\diamond$ The organization should have a Managerial Accounting area at the company;

$\diamond$ The person in charge of Managerial Accounting should be familiar with the topic in question;

$\checkmark$ The respondent should be willing and have time available to participate;

- The organization should be easily accessible;

$\diamond$ The organization should not consider the approach of the questionnaire as confidential data.

- Data gathering instrument: The technique used for data gathering was that of extensive direct documentation through the questionnaire comprising a series of questions, considering the need indicated by the theories raised, making use of a Likert scale, given its easy construction and understanding by the respondents. For each one of the 80 questions the respondents were asked to indicate the following, on a scale of five points ( $1=$ never used, does not contribute; 5 = always used, contributes a great deal):

$\diamond$ Frequency of use: How frequent is the use of accounting practices in the managerial accounting of the organization?

$\diamond$ Degree of contribution: Which is the degree of contribution of the method in making the result calculated by accounting principles close

\section{Conclusion}

Classical authors currently emphasize the importance of value in the perspective of corporate management. Value management implies Managerial Accounting structured in such a way as to focus on the creation of value in different business situations and levels of the organization. In this context, the paper analyzed the interaction and conflict between the prescriptive approach, which presents how information should be gathered and prepared, and the descriptive approach, representing the status quo of companies in the country.

For this evaluation the adjustments suggested by users of the EVA technique were used as a basis to determine which methods are used the most often and their relation with the controller's perception in approximating accounting data to the company's economic result. The most important aspects perceived in the onsite survey are:

- Controllers show concern with the implementation of a consistent information structure that supports the decision-making process, in the form of Managerial Accounting, increasing the odds of better performance and perpetuation of the company;

- The most frequently used methods are the same used in Financial Accounting: straight-line depreciation, allowance for doubtful accounts and valuation of inventories by the mobile weighted average. One of the explanations for this is that the adjustment cannot produce more work than the return that it provides through gains in the more efficient allocation of funds;

- The general perception of controllers is that all the methods contribute to approximate the accounting data to the economic result, with a minimum of $44 \%$ and a maximum of $95 \%$ respondents that recognize its contribution, at 
different degrees of intensity. The most frequently mentioned are: allowance for doubtful accounts, provision for contingency and provision for guarantee, besides all the respective adjustments;

- $72 \%$ of regressions showed evidence of a statistically significant relation, confirming that the controller's perception of contribution provided by the method in approximating the accounting and economic data is directly related to the frequency of use of this method at the company.

Table 1.a Distribution of Controllers According to the Perception of Proximity

\begin{tabular}{|c|c|c|c|c|c|}
\hline \multirow[t]{2}{*}{ Methods } & \multicolumn{5}{|c|}{ Perception of Control } \\
\hline & 1 & 2 & 3 & 4 & 5 \\
\hline \multicolumn{6}{|l|}{ Type 1 Adjustments } \\
\hline \multicolumn{6}{|l|}{ Research and development } \\
\hline Amortization in the contribution period & $14 \%$ & $6 \%$ & $6 \%$ & $27 \%$ & $46 \%$ \\
\hline Enter as operating expenses & $38 \%$ & $16 \%$ & $13 \%$ & $8 \%$ & $25 \%$ \\
\hline \multicolumn{6}{|l|}{ Goodwill } \\
\hline Recognition and accounting in assets & $19 \%$ & $0 \%$ & $10 \%$ & $24 \%$ & $48 \%$ \\
\hline $\begin{array}{l}\text { Writte-off of the amount in equity on } \\
\text { the adquisition date }\end{array}$ & $56 \%$ & $13 \%$ & $13 \%$ & $3 \%$ & $16 \%$ \\
\hline \multicolumn{6}{|l|}{ Amortization of goodwill } \\
\hline $\begin{array}{l}\text { Recognition of loss when activity is } \\
\text { concluded }\end{array}$ & $27 \%$ & $8 \%$ & $6 \%$ & $13 \%$ & $46 \%$ \\
\hline $\begin{array}{l}\text { Amortization in the period of economic } \\
\text { benefit }\end{array}$ & $22 \%$ & $10 \%$ & $11 \%$ & $21 \%$ & $37 \%$ \\
\hline Maintenance of the goodwill value intact & $56 \%$ & $13 \%$ & $14 \%$ & $6 \%$ & $11 \%$ \\
\hline Recognition of loss (impairment) & $19 \%$ & $10 \%$ & $10 \%$ & $16 \%$ & $46 \%$ \\
\hline $\begin{array}{l}\text { Writte-off of resulting from divestiture } \\
\text { or extinction }\end{array}$ & $24 \%$ & $8 \%$ & $11 \%$ & $18 \%$ & $40 \%$ \\
\hline \multicolumn{6}{|l|}{ Leasing } \\
\hline Leasing as a rent expense & $38 \%$ & $22 \%$ & $6 \%$ & $8 \%$ & $25 \%$ \\
\hline Leasing as a debt & $19 \%$ & $10 \%$ & $11 \%$ & $21 \%$ & $40 \%$ \\
\hline Financial leasing & $25 \%$ & $13 \%$ & $11 \%$ & $21 \%$ & $30 \%$ \\
\hline \multicolumn{6}{|l|}{ Deferred Taxes } \\
\hline Deferred Taxes & $14 \%$ & $3 \%$ & $11 \%$ & $27 \%$ & $44 \%$ \\
\hline Taxes deferred at present value & $11 \%$ & $3 \%$ & $5 \%$ & $30 \%$ & $51 \%$ \\
\hline \multicolumn{6}{|l|}{ Depreciation } \\
\hline Straight-line depreciation & $13 \%$ & $21 \%$ & $19 \%$ & $22 \%$ & $25 \%$ \\
\hline Depreciation by hours of operation ог UP & $21 \%$ & $6 \%$ & $3 \%$ & $32 \%$ & $38 \%$ \\
\hline Exponencial depreciation & $37 \%$ & $13 \%$ & $29 \%$ & $14 \%$ & $8 \%$ \\
\hline \multicolumn{6}{|l|}{ Type 2 Adjustments } \\
\hline \multicolumn{6}{|l|}{ Inventory Movement } \\
\hline LIFO method & $44 \%$ & $8 \%$ & $19 \%$ & $8 \%$ & $21 \%$ \\
\hline FIFO method & $52 \%$ & $13 \%$ & $11 \%$ & $11 \%$ & $13 \%$ \\
\hline
\end{tabular}


Table 1.a (continue)

\begin{tabular}{|c|c|c|c|c|c|}
\hline \multirow[t]{2}{*}{ Methods } & \multicolumn{5}{|c|}{ Perception of Control } \\
\hline & 1 & 2 & 3 & 4 & 5 \\
\hline Mobile weighted average method & $18 \%$ & $6 \%$ & $27 \%$ & $16 \%$ & $33 \%$ \\
\hline Different cost and last purchase method & $22 \%$ & $8 \%$ & $13 \%$ & $18 \%$ & $40 \%$ \\
\hline \multicolumn{6}{|l|}{$\begin{array}{l}\text { Provision for guarantee, contingency } \\
\text { and doubtful accounts }\end{array}$} \\
\hline Provision for guarantee & $11 \%$ & $11 \%$ & $8 \%$ & $25 \%$ & $44 \%$ \\
\hline Adjustment of provision for guarantee & $19 \%$ & $13 \%$ & $10 \%$ & $18 \%$ & $41 \%$ \\
\hline Provision of contingency & $10 \%$ & $3 \%$ & $10 \%$ & $35 \%$ & $43 \%$ \\
\hline Adjustmen of provision for contingency & $21 \%$ & $8 \%$ & $13 \%$ & $18 \%$ & $41 \%$ \\
\hline Allowance for doubtful accounts & $5 \%$ & $5 \%$ & $8 \%$ & $21 \%$ & $62 \%$ \\
\hline $\begin{array}{l}\text { Adjustment for allowance of doubtful } \\
\text { accounts }\end{array}$ & $18 \%$ & $11 \%$ & $8 \%$ & $11 \%$ & $52 \%$ \\
\hline \multicolumn{6}{|l|}{ Type 3 Adjustments } \\
\hline \multicolumn{6}{|l|}{ Non-recurrent gains and losses } \\
\hline Isolating non-recurrent real res. events & $11 \%$ & $5 \%$ & $10 \%$ & $19 \%$ & $56 \%$ \\
\hline Isolating non-recurrent proj. res. events & $22 \%$ & $13 \%$ & $18 \%$ & $13 \%$ & $35 \%$ \\
\hline Expurgating non-recurrent real res. events & $52 \%$ & $11 \%$ & $11 \%$ & $14 \%$ & $11 \%$ \\
\hline Expurgating non-recurrent proj. res. events & $51 \%$ & $10 \%$ & $11 \%$ & $16 \%$ & $13 \%$ \\
\hline
\end{tabular}

Source: Prepared by the author. (1) Does not contribute; (2) Contributes a little; (3) Contributes to a moderate degree; (4) Contributes and (5) Contributes a lot.

Table 1.b Distribution of Controllers According to the Frecuency of Use of the Method

\begin{tabular}{|l|c|c|c|c|c|}
\hline \multicolumn{1}{|c|}{ Methods } & \multicolumn{5}{|c|}{ Frequency of Use } \\
\hline & 1 & 2 & 3 & 4 & 5 \\
\hline Type 1 Adjustments & & & & & \\
\hline Research and development & & & & & \\
\hline Amortization in the contribution period & $38 \%$ & $6 \%$ & $11 \%$ & $16 \%$ & $29 \%$ \\
\hline Enter as operating expenses & $41 \%$ & $14 \%$ & $6 \%$ & $14 \%$ & $24 \%$ \\
\hline Goodwill & & & & & \\
\hline $\begin{array}{l}\text { Recognition and accounting in assets } \\
\text { Writte-off of the amount in equity on } \\
\text { the adquisition date }\end{array}$ & $49 \%$ & $3 \%$ & $5 \%$ & $10 \%$ & $33 \%$ \\
\hline Amortization of goodwill & $75 \%$ & $13 \%$ & $3 \%$ & $5 \%$ & $5 \%$ \\
\hline $\begin{array}{l}\text { Recognition of loss when activity is } \\
\text { concluded }\end{array}$ & $64 \%$ & $8 \%$ & $3 \%$ & $3 \%$ & $22 \%$ \\
\hline $\begin{array}{l}\text { Amortization in the period of economic } \\
\text { benefit }\end{array}$ & & & & & \\
\hline
\end{tabular}


Table 1.b (continue)

\begin{tabular}{|c|c|c|c|c|c|}
\hline \multirow[t]{2}{*}{ Methods } & \multicolumn{5}{|c|}{ Frequency of Use } \\
\hline & 1 & 2 & 3 & 4 & 5 \\
\hline Maintenance of the goodwill value intact & $67 \%$ & $8 \%$ & $8 \%$ & $8 \%$ & $10 \%$ \\
\hline Recognition of loss (impairment) & $54 \%$ & $14 \%$ & $2 \%$ & $13 \%$ & $18 \%$ \\
\hline $\begin{array}{l}\text { Writte-off of resulting from divestiture } \\
\text { or extinction }\end{array}$ & $52 \%$ & $11 \%$ & $3 \%$ & $6 \%$ & $27 \%$ \\
\hline \multicolumn{6}{|l|}{ Leasing } \\
\hline Leasing as a rent expense & $33 \%$ & $8 \%$ & $5 \%$ & $13 \%$ & $41 \%$ \\
\hline Leasing as a debt & $68 \%$ & $11 \%$ & $8 \%$ & $6 \%$ & $6 \%$ \\
\hline Financial leasing & $62 \%$ & $10 \%$ & $6 \%$ & $8 \%$ & $14 \%$ \\
\hline \multicolumn{6}{|l|}{ Deferred Taxes } \\
\hline Deferred Taxes & $33 \%$ & $2 \%$ & $18 \%$ & $11 \%$ & $37 \%$ \\
\hline Taxes deferred at present value & $54 \%$ & $13 \%$ & $11 \%$ & $3 \%$ & $19 \%$ \\
\hline \multicolumn{6}{|l|}{ Depreciation } \\
\hline Straight-line depreciation & $8 \%$ & $3 \%$ & $2 \%$ & $14 \%$ & $73 \%$ \\
\hline Depreciation by hours of operation or UP & $65 \%$ & $11 \%$ & $3 \%$ & $8 \%$ & $13 \%$ \\
\hline Exponencial depreciation & $89 \%$ & $6 \%$ & $0 \%$ & $0 \%$ & $5 \%$ \\
\hline \multicolumn{6}{|l|}{ Type 2 Adjustments } \\
\hline \multicolumn{6}{|l|}{ Inventory Movement } \\
\hline LIFO method & $81 \%$ & $8 \%$ & $2 \%$ & $0 \%$ & $10 \%$ \\
\hline FIFO method & $73 \%$ & $5 \%$ & $6 \%$ & $3 \%$ & $13 \%$ \\
\hline Mobile weighted average method & $19 \%$ & $3 \%$ & $5 \%$ & $8 \%$ & $65 \%$ \\
\hline Different cost and last purchase method & $57 \%$ & $8 \%$ & $16 \%$ & $10 \%$ & $10 \%$ \\
\hline \multicolumn{6}{|l|}{$\begin{array}{l}\text { Provision for guarantee, contingency } \\
\text { and doubtful accounts }\end{array}$} \\
\hline Provision for guarantee & $48 \%$ & $11 \%$ & $6 \%$ & $3 \%$ & $32 \%$ \\
\hline Adjustment of provision for guarantee & $59 \%$ & $13 \%$ & $10 \%$ & $3 \%$ & $16 \%$ \\
\hline Provision of contingency & $37 \%$ & $8 \%$ & $8 \%$ & $18 \%$ & $30 \%$ \\
\hline Adjustmen of provision for contingency & $46 \%$ & $10 \%$ & $10 \%$ & $10 \%$ & $25 \%$ \\
\hline Allowance for doubtful accounts & $16 \%$ & $8 \%$ & $10 \%$ & $6 \%$ & $60 \%$ \\
\hline $\begin{array}{l}\text { Adjustment for allowance of doubtful } \\
\text { accounts }\end{array}$ & $38 \%$ & $13 \%$ & $5 \%$ & $8 \%$ & $37 \%$ \\
\hline \multicolumn{6}{|l|}{ Type 3 Adjustments } \\
\hline \multicolumn{6}{|l|}{ Non-recurrent gains and losses } \\
\hline Isolating non-recurrent real res. events & $19 \%$ & $8 \%$ & $8 \%$ & $10 \%$ & $56 \%$ \\
\hline Isolating non-recurrent proj. res. events & $40 \%$ & $11 \%$ & $8 \%$ & $5 \%$ & $37 \%$ \\
\hline Expurgating non-recurrent real res. events & $75 \%$ & $10 \%$ & $6 \%$ & $3 \%$ & $6 \%$ \\
\hline Expurgating non-recurrent proj. res. events & $65 \%$ & $13 \%$ & $6 \%$ & $3 \%$ & $13 \%$ \\
\hline
\end{tabular}

Source: Prepared by the author. (1) Is never used; (2) Infrequently used; (3) Used to a moderate degree; (4) Used frequently and (5) Always used. 
- The author calculated the correlations between and among the variables, confirming the relation evidenced in regressions. For the other variables that did not present a statistically significant relation, the author observes a starting point for expounding on the analysis of the topic, seeking the validation of other theories. In this case, a qualitative survey with in-depth interviews is suggested.

Table 2. Summary of the Survey - Significance Index

\begin{tabular}{|c|c|c|c|}
\hline Methods & $\begin{array}{l}\text { Index of } \\
\text { Significance }\end{array}$ & Rating & $\begin{array}{c}\text { Coefficient } \\
\mathrm{b}\end{array}$ \\
\hline \multicolumn{4}{|l|}{ Type 1 Adjustments } \\
\hline \multicolumn{4}{|l|}{ Research and development } \\
\hline $\begin{array}{l}\text { Amortization in the contribution } \\
\text { period }\end{array}$ & 0.062 & not significant & - \\
\hline Enter as operating expenses & 0.001 & significant & 0.427 \\
\hline \multicolumn{4}{|l|}{ Goodwill } \\
\hline $\begin{array}{l}\text { Recognition and accounting in } \\
\text { assets }\end{array}$ & 0.207 & not significant & - \\
\hline $\begin{array}{l}\text { Writte-off of the amount in } \\
\text { equity on the adquisition date }\end{array}$ & 0.033 & significant & 0.195 \\
\hline \multicolumn{4}{|l|}{ Amortization of goodwill } \\
\hline $\begin{array}{l}\text { Recognition of loss when activity is } \\
\text { concluded }\end{array}$ & 0.002 & significant & 0.375 \\
\hline $\begin{array}{l}\text { Amortization in the period of } \\
\text { economic benefit }\end{array}$ & 0.029 & significant & 0.293 \\
\hline $\begin{array}{l}\text { Maintenance of the goodwill value } \\
\text { intact }\end{array}$ & 0.001 & significant & 0.394 \\
\hline Recognition of loss (impairment) & 0.000 & significant & 0.461 \\
\hline $\begin{array}{l}\text { Writte-off of resulting from } \\
\text { divestiture or extinction }\end{array}$ & 0.000 & significant & 0.487 \\
\hline \multicolumn{4}{|l|}{ Leasing } \\
\hline Leasing as a rent expense & 0.519 & not significant & - \\
\hline Leasing as a debt & 0.081 & not significant & - \\
\hline Financial leasing & 0.029 & significant & 0.262 \\
\hline \multicolumn{4}{|l|}{ Deferred Taxes } \\
\hline Deferred taxes & 0.000 & significant & 0.626 \\
\hline Taxes deferred at present value & 0.046 & significant & 0.304 \\
\hline \multicolumn{4}{|l|}{ Depreciation } \\
\hline Straight-line depreciation & 0.006 & significant & 0.295 \\
\hline $\begin{array}{l}\text { Depreciation by hours of operation } \\
\text { or UP }\end{array}$ & 0.378 & not significant & - \\
\hline Exponencial depreciation & 0.012 & significant & 0.209 \\
\hline \multicolumn{4}{|l|}{ Type 2 Adjustments } \\
\hline \multicolumn{4}{|l|}{ Inventory movement } \\
\hline LIFO method & 0.005 & significant & 0.261 \\
\hline
\end{tabular}


Table 2. (continue)

\begin{tabular}{|l|c|c|c|}
\hline \multicolumn{1}{|c|}{ Methods } & $\begin{array}{c}\text { Index of } \\
\text { Significance }\end{array}$ & Rating & $\begin{array}{c}\text { Coefficient } \\
\text { b }\end{array}$ \\
\hline FIFO method & 0.044 & significant & 0.244 \\
\hline Mobile weighted average method & 0.965 & not significant & - \\
\hline $\begin{array}{l}\text { Different cost and last purchase } \\
\text { method }\end{array}$ & 0.023 & significant & 0.252 \\
\hline $\begin{array}{l}\text { Provision for guarantee, contingency } \\
\text { and doubtful accounts }\end{array}$ & & & \\
\hline Provision for guarantee & 0.004 & significant & 0.454 \\
\hline $\begin{array}{l}\text { Adjustment of provision for } \\
\text { guarantee }\end{array}$ & 0.005 & significant & 0.331 \\
\hline Provision of contingency & 0.001 & significant & 0.579 \\
\hline $\begin{array}{l}\text { Adjustmen of provision for } \\
\text { contingency }\end{array}$ & 0.000 & significant & 0.528 \\
\hline Allowance for doubtful accounts & 0.000 & significant & 0.717 \\
\hline $\begin{array}{l}\text { Adjustment for allowance of } \\
\text { doubtful accounts }\end{array}$ & 0.000 & significant & 0.694 \\
\hline $\begin{array}{l}\text { Type 3 Adjustments } \\
\text { Non-recurrent gains and losses }\end{array}$ & 0.172 & not significant & - \\
\hline $\begin{array}{l}\text { Isolating non-recurrent real res. } \\
\text { events }\end{array}$ & 0.048 & not significant & - \\
\hline $\begin{array}{l}\text { Isolating non-recurrent proj. res. } \\
\text { events }\end{array}$ & significant & 0.298 \\
\hline $\begin{array}{l}\text { Expurgating non-recurrent real res. } \\
\text { events }\end{array}$ & & & 0.526 \\
\hline $\begin{array}{l}\text { Expurgating non-recurrent proj. res. } \\
\text { events }\end{array}$ & & & \\
\hline
\end{tabular}

Source: Prepared by the author. At which: level of significance $<0.05(95 \%)$

\section{References}

Carvalho, E. (1999). A Relação entre o EVA (Economic Value Added) e o Valor das Ações na Bolsa de Valores do Estado de São Paulo. São Paulo. Dissertation (Master's Degree in Accounting and Controllership) - Economics, Administration and Accounting College of São Paulo University.

Copeland, T., T. Koller, and J. Murrin (1995). Valuation: Measuring and Managing the Value of Companies. New York: Wiley.

Doucouliagos, C. (1994). A Note on the Evolution of Homo Economicus. Journal of Economic Issues, 28 , Sept.

Fipecafi (1994). Manual de Contabilidade das Sociedades por Ações - Aplicável também às demais Sociedades. 3 ed. rev. and current. São Paulo: Atlas.

Frezatti, F. (1996). Contribuição para o Estudo da Complementaridade do Lucro e do Fluxo de Caixa na Gestão de Negócios no Ambiente Empresarial Brasileiro. São Paulo. Thesis 
(Doctor's Degree in Accounting and Controllership) - Economics, Administration and Accounting College of São Paulo University,

Frezatti, F. (1998). Valor da Empresa: avaliação de Ativos pela Abordagem do Resultado Econômico Residual. Cadernos de Estudos, São Paulo, FIPECAFI, 10(19), pp. 57-69, Sept./Dec.

Frezatti, F. (2001). Contributeção para o Estudo do Market Value Added como Indicador de Eficiência na Gestão do Valor: uma Análise das Empresas Brasileiras com Ações Negociadas em Bolsa de Valores no Ambiente Brasileiro Pós-Plano Real. São Paulo, Thesis (Livre-Docência em Contabilidade e Atuária) - Economics, Administration and Accounting College of São Paulo University.

Frezatti, F. (2003). Gestão de Valor na Empresa: Uma Abordagem Abrangente do Valuation a Partir da Contabilidade Gerencial. São Paulo: Atlas.

Hendriksen, E. and M. Breda (1992). Accounting Theory. 5 ed. Boston, Irwin.

Johnson, H. and R Kaplan (1996). A Relevância da Contabilidade de Custos. 2. ed. Rio de Janeiro: Campus.

Leão, L., A. Santos, and P. Lustosa (2000). Impostos Diferidos: Crepúsculo ou Amanhecer do Princípio da Competência? In: Brazilian Accounting Congress, n. 16, Brasília: Federal Accounting Council.

Martins, E. (1992). Contabilidade de Custos. 4 ed. rev. São Paulo: Atlas.

Martins, E. (2002). A Posição do Conselho Federal de Contabilidade com Relação ao Arrendamento Mercantil: aplausos! Temática Contábil e Balanços. IOB Bulletin, 13, pp.1-8.

Milani, N. (1982). A Problemática da Determinação do Custo de Survey e Development e de sua Contabilização. São Paulo. Dissertation (Master's Degree in Controllership and Accounting) - Economics, Administration and Accounting College of São Paulo University.

Rappaport, A. (1981). Selecting Strategies that Create Shareholder Value. Harvard Business Review. pp. 139-149, May/June.

Reis, E. (1997). Aspectos da Depreciation de Ativos Sob a ótica da Gestão Econômica. São Paulo, Thesis (Master's Degree in Accounting and Controllership) - Economics, Administration and Accounting College of São Paulo University.

Sundararajan, V. (2002). Accounting for Goodwill. Available at: http://home.att.net/ sprasad/GW.htm\#top. Access on: Dec.31.

Van Horne, J. (1975). Financial Management \& Policy. London, Prentice-Hall.

Young, S. and S. O'byrne (2000). EVA and Value-Based Management: A Practical Guide to Implementation. McGraw-Hill.

Young, S. (1999). Some Reflections on Accounting Adjustments and Economic Value Added. Journal of Financial Statement Analysis, 4(2), pp. 1-13, winter. 